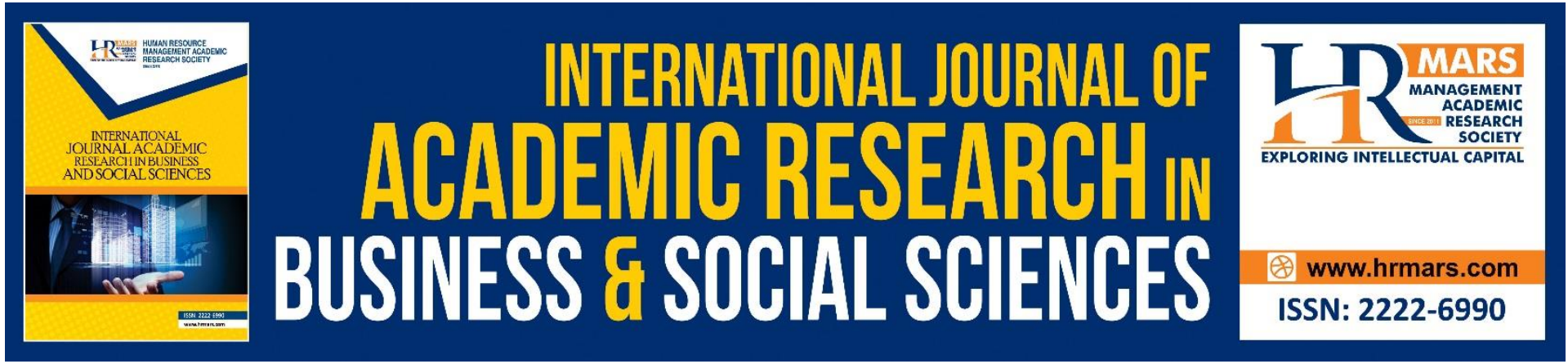

\title{
The Mission to Develop Godly Individuals: An Islamic Perspective
}

Kabuye Uthman Sulaiman

To Link this Article: http://dx.doi.org/10.6007/IJARBSS/v11-i8/10348

DOI:10.6007/IJARBSS/v11-i8/10348

Received: 09 June 2021, Revised: 12 July 2021, Accepted: 30 July 2021

Published Online: 22 August 2021

In-Text Citation: (Sulaiman, 2021)

To Cite this Article: Sulaiman, K. U. (2021). The Mission to Develop Godly Individuals: An Islamic Perspective. International Journal of Academic Research in Business and Social Sciences, 11(8), 799-818.

Copyright: (c) 2021 The Author(s)

Published by Human Resource Management Academic Research Society (www.hrmars.com)

This article is published under the Creative Commons Attribution (CC BY 4.0) license. Anyone may reproduce, distribute, translate and create derivative works of this article (for both commercial and non-commercial purposes), subject to full attribution to the original publication and authors. The full terms of this license may be seen at: http://creativecommons.org/licences/by/4.0/legalcode

Vol. 11, No. 8, 2021, Pg. 799 - 818

Full Terms \& Conditions of access and use can be found at http://hrmars.com/index.php/pages/detail/publication-ethics 


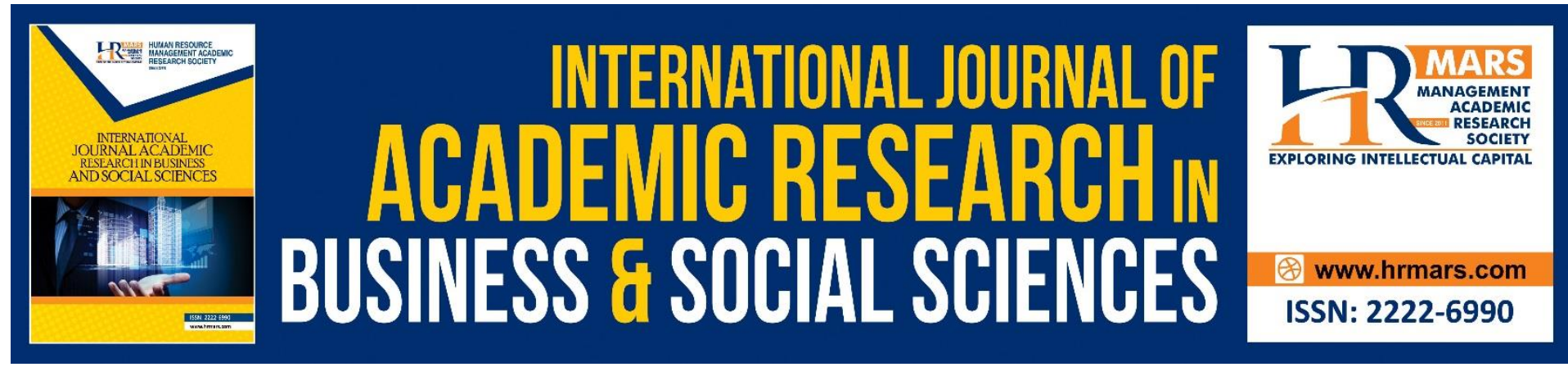

\title{
The Mission to Develop Godly Individuals: An Islamic Perspective
}

\author{
Kabuye Uthman Sulaiman
}

Department of Fundamental and Inter-Disciplinary Studies, Kulliyyah of Islamic Revealed Knowledge and Human Sciences, International Islamic University Malaysia

Email: kabuye@iium.edu.my

\begin{abstract}
The main purpose for the establishment of Islamic educational institutions is to offer a God (Allah)-centered curriculum with the mission to develop godly (virtuous, honest, compassionate and responsible) students who will be able to contribute significantly to moral, spiritual and physical welfare of humanity in general, and bring back the past glory and fame of the ummah (Muslim community) in particular. The aim of this paper is to describe godliness from the view point of the Qur'an and the Hadith or Sunnah (Prophetic traditions or the narrations of sayings, doings or silent approvals of Prophet Muhammad (peace be upon him - PBUH). This paper is divided into three sub-topics, namely meaning and significance of godliness, characteristics of a godly person, and the means to attain godliness. Godliness or devotion (submission and obedience) to Allah is the sole reason for the creation of mankind and Jinns, "I have only created Jinns and men, that they may serve Me - liya 'budun;" (Qur'an, 51:56) but also everything else (the entire universe). Also it is because of godliness that the Prophets (peace be upon them) were sent to mankind, "Not an apostle did We send before thee without this inspiration sent by Us to him: that there is no god but I; therefore, worship and serve Me -fa'budun." (Qur'an, 21:25). Here it is clear that there is a higher purpose to the creation of mankind and the Jinns, namely 'ibadatu'llah, devotion to Allah. It means recognition of Allah and subsequent submission or humility and obedience to Him.
\end{abstract}

Keywords: Godliness, God-centeredness, Righteousness, Amanah, Al-Amn (Inner Peace).

\section{Introduction}

Social ills such as lack of self-discipline, irresponsibility or fulfilment of amanah (obligations), vandalism, racial discrimination, environmental discrimination, terrorism and corruption arise as a result of self-centeredness and education without God. This study aims at describing godliness from the view point of the Qur'an and the Hadith or Sunnah (Prophetic traditions or the narrations of sayings, doings or silent approvals of Prophet Muhammad (peace and blessings be upon him)) to achieve the following objectives:

1) Extrapolate the meaning of godliness and its significance with reference to the selected Qur'anic verses and Hadith.

2) Identify the characteristics of godly individuals based on the selected Qur'anic verses and Hadith or Sunnah. 
Enlighten the readers (students, community and researchers) on the need and significance of godliness and a God-centered curriculum or education.

1) Show the importance of iqra' (education) to Godliness.

2) Highlight the manners of seeking knowledge in Islam.

The research questions developed for this study are:

1) What is godliness?

2) What is the significance of godliness to human life?

3) What are the characteristics of a godly person?

4) What are the means to attain godliness?

5) What are the key characteristics of a God-centered curriculum or education?

To achieve the above-mentioned objectives, this study is divided into three sections: meaning and significance of godliness, characteristics of a godly person from the perspective of the Qur'an and Hadith or Sunnah, and means to attain godliness. By the end of this article readers will be able to grasp the meaning and significance of godliness from the standpoint of Islam, the characteristics of a godly person, a God-centered curriculum or education based on the first five revealed verses of the Qur'an, and the means to attain godliness.

\section{Meaning and Significance of Godliness}

Godliness is the quality of being righteous and God-centred. The Islamic or Arabic concepts for righteousness and God-centeredness are birr and rabbaniyyah respectively. Birr is interpreted as "the action that provides peace and contentment to a person and ends his anxiety and the worry of his conscience." (IFEW -Islamic Foundation for Education \& Welfare, n.d). Allah says (interpretation of the meaning):

"It is not righteousness that ye turn your faces Towards east or West; but it is righteousness to believe in Allah and the Last Day, and the Angels, and the Book, and the Messengers; to spend of your substance, out of love for Him, for your kin, for orphans, for the needy, for the wayfarer, for those who ask, and for the ransom of slaves; to be steadfast in prayer, and practice regular charity; to fulfil the contracts which ye have made; and to be firm and patient, in pain (or suffering) and adversity, and throughout all periods of panic. Such are the people of truth, the Allah-fearing." (Qur'an, 2:177).

Al-Nawwas bin Sam'an (may Allah be pleased with him) reported that the Prophet (PBUH) said: "Righteousness is good character, and sin is that which wavers in your heart and which you do not want people to know about." (Al-Hajjaj (Muslim), 2553, Sahih).

The verse above mentions three ingredients of righteousness or the characteristics of a godly person, namely: (1) to have iman (belief) in Allah, the Last Day, the angels, the Book, and the Prophets; (2) to render service to humanity by spending from what one loves earnestly (material things), which also means, to fulfil the needs of one's fellow-beings in spite of one's natural desire to keep the material things for one's self; (3) to be steadfast in prayer, and practice regular charity; (4) to honour or fulfil agreements; (5) to be patient in times of poverty, ailment and war or conflict.

It is understood from the above verse that: first, iman is the main foundation of a Muslim's righteous acts, and this is why it is at the forefront of the righteous acts in the above verse; and second, true righteousness or godliness partly lies in higher moral values such as rendering assistance to others. Therefore, unlike a self-and flesh-centred person who is concerned solely with himself and his physiological needs (desires and interests), and therefore, he is egocentric, egoistic and egoistical, a godly person is selfless, loving and merciful. He connects with Allah and others. 
Rabbaniyyah (God-centeredness or "the attribute of being related to God, Allah) denotes sincere devotion (submission and surrender) to Allah, seeking Him above all else. This includes worship of Him alone, following His Orders and abstaining from His Prohibitions, acceptance of His decrees and obedience to His Prophets (peace be upon them) and those charged with authority among mankind. Allah says (interpretation of the meaning):

"O ye who believe! Obey Allah, and obey the Messenger, and those charged with authority among you. If ye differ in anything among yourselves, refer it to Allah and His Messenger, if ye do believe in Allah and the Last Day: That is best, and most suitable for final determination." (Qur'an, 4:59).

"Obey Allah, and obey the Messenger, and beware (of evil): if ye do turn back, know ye that it is Our Messenger's duty to proclaim (the message) in the clearest manner." (Qur'an, 5:92). It is worth noting here that, first, the Messenger's sole duty is to deliver Allah's Message to the people. Therefore, obedience to Allah and obedience to the Messenger are the same thing; and second, those charged with authority include one's parents, husband, employer, also head of state, police and other governing authorities, as long as their commands do not contravene with Allah's commands or as long as they don't disregard justice.

People obey orders to be rewarded for their obedience and to avoid the negative consequences of disobedience or rebellion against authority. The Qur'an mentions many nations that were destroyed because they disobeyed Allah's Messengers and ignored His laws:

"And the people of Noah, when they rejected the apostles, We drowned them, and We made them as a Sign for mankind; and We have prepared for (all) wrong-doers a grievous Penalty. As also 'Ad and Thamud, and the Companions of the Rass, and many a generation between them. To each one We set forth Parables and examples; and each one We broke to utter annihilation (for their sins)." (Qur'an, 25:37-39).

Yohannan likens a rebellious or disobedient person to a stray sheep; it runs away from safety and heads for destruction:

"It is the job of the shepherd to protect the sheep. Do you know what happens to a sheep that has gone astray? It is actually walking into the territory of its predators. When a pack of wolves is hunting, their instinctive goal is to go after any animal that has strayed. A wandering sheep has no shepherd to protect it, and it soon gets torn apart by ravaging wolves. When we step out from under the covering of our authority, we become like that wandering sheep. The grass may look delightfully green on the outside of the fold, and we can sigh, "I'm tired of all these rules and regulations. I know my own way. I know what to do." But we are wandering into the territory of demons who are looking for any who have walked away from the protection of their authority. (Yohannan, 2008, pp. 49-50).

It is understood from the above that "to stray" means "to perish." Therefore, to be safe one must be in constant communion with Allah. He or she must have a daily devotional time with Him. They must show obedience to Allah and His Messengers, and to those vested with authority. Allah says (interpretation of the meaning):

"He said: "Get ye down, both of you, all together, from the Garden, with enmity one to another: but if, as is sure, there comes to you Guidance from Me, whosoever follows My Guidance, will not lose his way, nor fall into misery. But whosoever turns away from My Message, verily for him is a life narrowed down, and We shall raise him up blind on the Day of Judgment."'" (Qur'an, 20:123-124).

Ultimately, those who are obedient to Allah will earn the best reward, being Paradise: "All who obey Allah and the apostle are in the company of those on whom is the Grace of Allah, 
of the prophets (who teach), the sincere (lovers of Truth), the witnesses (who testify), and the Righteous (who do good): Ah! what a beautiful fellowship! Such is the bounty from Allah. And sufficient is it that Allah knoweth all." (Qur'an, 4:69-70).

\section{Attributes of A Godly Person from the Perspective of The Qur'an and Hadith or Sunnah}

A godly person is characterized by spiritual, moral and intellectual attributes. The aim of this section is describe these attributes from the perspective of the Qur'an and Hadith or Sunnah.

\section{Spiritual Attributes}

The Qur'an describes several spiritual attributes or values of a godly person. However, in this section we shall only describe a few which we believe to be the most essential. They are as follows:

\section{Al-Taqwa}

Al-Taqwa is the most emphasized spiritual virtue in Islam. Allah says (interpretation of the meaning):

"For Hajj are the months well known. If anyone undertakes that duty therein, let there be no obscenity, nor wickedness, nor wrangling in the Hajj. And whatever good ye do, (be sure) Allah knoweth it. And take a provision (With you) for the journey, but the best of provisions is right conduct (al-Taqwa). So fear Me, o ye that are wise." (Qur'an, 2:197).

"What is al-Taqwa?" 'Umar Ibn Al-Khattab (may Allah be pleased with him) asked 'Ubayy Ibn Ka'ab (may Allah be pleased with him). 'Ubayy responded asking: "Have you ever taken a thorny path?" 'Umar replied in the affirmative. Then 'Ubayy asked again: "So how did you travel along this thorny path?" 'Umar replied: "I rolled up my garment and was cautious as to where I would tread to avoid being pricked by the thorns." So 'Ubayy responded and said: "This is al-Taqwa." Hence, Al-Taqwa means God-consciousness, guarding of oneself and being careful of one's duties to Allah, oneself and others. Its indicators are: first, complete submission and obedience to Allah, which means, compliance with His orders, and second, abstinence from His prohibitions.

\section{Al-Dzullu (Humility and Politeness)}

Humility is regarded as the highest of all virtues (Sivananda, 2011, p.8). Allah says (interpretation of the meaning): "And the servants of (Allah) Most Gracious are those who walk on the earth in humility, and when the ignorant address them, they say, "Peace!"” (Qur'an, 25:63).

The Prophet Muhammad (PBUH) was humble and polite. He always mingled with the downtrodden people, namely the poor and slaves; he was respectful to women and treated everyone in a brotherly manner. He regarded politeness as 'charity.' (Ibn Hibban, 476, Sahih). Mu'awiyah ibn al-Hakam (may Allah be pleased with him) reported:

"I was praying with the Messenger of Allah (PBUH) while a man among the people sneezed, so I said, "May Allah have mercy on you!" The people began to glare at me in disapproval. When the Prophet finished the prayer, by my father and mother, I have not seen a better teacher before or after him. By Allah, the Prophet did not scold me, hit me, or revile me. The Prophet said, "Verily, it is not correct for this prayer to contain any human speech. Rather, only the glorification and exaltation of Allah, and the recitation of the Qur'an."'” (Muslim, 537, Sahih). 
Humility and politeness were also among the good advice Luqman gave to his son. He said: "And swell not thy cheek (for pride) at men, nor walk in insolence through the earth; for Allah loveth not any arrogant boaster. And be moderate in thy pace, and lower thy voice; for the harshest of sounds without doubt is the braying of the ass." (Qur'an, 31:18-19).

A humble person is the one who does not see himself as better than others because of colour, language, race, education, wealth, etc.; one who is willing to accept his shortcomings: "Taking on a disposition of humility and learning keeps us open to changing ourselves and consequently keeps us from claiming to be perfect" (Welter \& Egmon, 2006, p.245).

Arrogance can deceive a heart to be foolishly critical, thus impatient to attain that which is only acquired through patience, humility and politeness. It is reported that 'Abdullah ibn 'Abbas (may Allah be pleased with him) said: "Dzalaltu taliban fa'azaztu matluban," meaning "I lowered myself seeking, and then I became sought" (Al-Zubaidi, 1971, p.152).

Being polite means respecting the feelings of others and not being rude to them; seeing goodness in others and not disclosing their faults. A polite student is the one who thanks the teacher for the knowledge even in the case of disagreement, he does not sit between two people without their permission, and when asking questions, he asks in a polite manner and listens to the answer attentively. Asking questions in a rude manner is disrespect to the teacher.

\section{Al-Ikhlas (sincerity)}

It is incumbent upon all Muslims to strive to preserve their niyyat, intentions, from being corrupted. Therefore, they should continuously keep a check on their intentions (muhasabah). The aim of muhasabah (review and inspection) is not just to know one's strength and achievements but more importantly to know one's shortcomings and failures in one's endeavours. One's niyyah (intention) is corrupted when one intends other than the sake of Allah (when seeking knowledge). It is worth noting that any deed through which Allah's pleasure is not sought is futile; it will bear no fruits in the Hereafter.

Abu Hurayrah (may Allah be pleased with him) reported: The Messenger of Allah (PBUH) said, "Verily, the first people to be judged on the Day of Resurrection will be a man who was martyred. He will be brought, the blessings of Allah will be made known, and he will acknowledge them. Allah will say: What did you do with them? The man will say: I fought in Your cause until I was martyred. Allah will say: You have lied, for you fought only that it would be said you were brave, thus it was said. Then, Allah will order him to be dragged upon his face until he is cast into Hellfire. Another man studied religious knowledge, taught others, and recited the Qur'an. He will be brought, the blessings of Allah will be made known, and he will acknowledge them. Allah will say: What did you do with them? The man will say: I learned religious knowledge, taught others, and I recited the Qur'an for Your sake. Allah will say: You have lied, for you studied only that it would be said you are a scholar and you recited the Qur'an only that it would be said you are a reciter, thus it was said. Then, Allah will order him to be dragged upon his face until he is cast into Hellfire. Another man was given an abundance of blessings from Allah and every kind of wealth. He will be brought, the blessings of Allah will be made known, and he will acknowledge them. Allah will say: What did you do about them? The man will say: I did not leave any good cause beloved to You but that I spent on it for Your sake. Allah will say: You have lied, for you spent only that it would be said you are generous, thus it was said. Then, Allah will order him to be dragged upon his face until he is cast into Hellfire." (Muslim, 1905, Sahih). 
Ikhlas is the implementation of la ilaha illa Allah (there is none worthy of worship but Allah), which is also known as kalimat al-lkhlas, meaning the phrase of Ikhlas. In Islam al-Tawhid forms an axis around which life revolves; it is the basis of all Man's actions. Allah says (interpretation of the meaning):

"And they have been commanded no more than this: To worship Allah, offering Him sincere devotion, being true (in faith); to establish regular prayer; and to practise regular charity; and that is the Religion Right and Straight." (Qur'an, 98:5).

Literally, Ikhlas means "to separate and distinguish" or "to filter." Allah says (interpretation of the meaning): "And verily in cattle (too) will ye find an instructive sign. From what is within their bodies between excretions and blood, We produce, for your drink, milk, pure and agreeable to those who drink it." (Qur'an, 16:66).

Technically, it is described as "keeping the action free from other-than-Allah having a role in it." Allah says (interpretation of the meaning): "Verily it is We Who have revealed the Book to thee in Truth: so serve Allah, offering Him sincere devotion." (Qur'an, 39:2).

While it may be easy to perform an action of the tongue or limbs, having Ikhlas is difficult. One of the scholars is quoted to have said, "Allah may accept from you half an action, but will not accept from you half an intention" (Abu Abbaad, 2014). Sufyan al-Thawri (may Allah be pleased with him) mentioned: "I did not try to rectify anything that was more difficult upon me than my intention" (AbdurRahman.org, September 30, 2014).

\section{Al-Amn (Inner peace)}

Al-Amn is a state of peace, calm, tranquillity and security; or a state of being free from fear and worry. Allah says (interpretation of the meaning), "It is those who believe and confuse not their beliefs with wrong (zulm) that are (truly) in security, for they are on (right) guidance." (Qur'an, 6:82). Here it is understood that Allah grants security and guidance to those who show respect to His Right, namely al-Tawhid (Oneness); those who worship none but Him Alone; those who discharge the amanat (sing. Amanah), the responsibilities. Al-Amn is achieved through the following:

First, beliefs such as:

a) Belief in al-Qadha' wa al-Qadar (predestination of things): Allah says (interpretation of the meaning): "Say: "Nothing will happen to us except what Allah has decreed for us: He is our protector" and on Allah let the Believers put their trust." (Qur'an, 9:51). From this verse it is understood that, first, belief in al-Qadha' wa alQadar means acknowledgement of Allah's rububiyyah (Lordship) and to rest assured that nothing will happen except what has been decreed by Allah; and second, belief in al-Qadha' wa al-Qadar (predestination of things) and al-Tawakkul 'ala Allah (putting one's trust in Allah) are complimentary to each other.

b) Belief in al-Wa'd (Allah's promises to the believers) that if they are grateful, $\mathrm{He}$ will increase them (Qur'an, 14:7); if they call Him, He will respond to them (Qur'an, 40:60); if they remember Him, He will remember them (Qur'an, 2:152); if they believe in Him and do good deeds, their reward shall be Paradise (Qur'an, 4:122); that He will not punish them while they seek forgiveness (Qur'an, 8:33); and that the end is for them: "Said Moses to his people: "Pray for help from Allah, and (wait) in patience and constancy: for the earth is Allah's to give as a heritage to such of His servants as He pleaseth; and the end is (best) for the righteous." (Qur'an, 7:128). Here it is understood that iman (having faith in Allah) and al-Sabr (patience and consistency) are also complimentary to each other and both are key to victory. 
Second, fulfilment of amanah (pl. Amanat). Allah says (interpretation of the meaning), "Those who faithfully observe their trusts (amanat) and their covenants." (Qur'an, 23:8). Amanah is a very comprehensive term as it includes all things that fall into one of the following categories: first, al-Wajibat or everything that Allah has enjoined upon human beings, such as belief in His Indivisible Oneness and worship of Him Alone, salat, zakat, sawm and hajj. These are called huquq Allah (Allah's Rights on His slaves); second, moral responsibilities such as the moral responsibility to look after the earth, enjoining good and forbidding wrong, respect for elders and mercy to the young ones; and thirdly, trusts or the things that we are required to look after. These are classified into two: (1) things that are entrusted to us by Allah (the Rights of Allah on His slaves) such as the earth to safeguard instead of destroying it by exploiting it in any way we wish and the faculties of hearing, seeing, understanding and feeling to show thanks to Him: "It is He Who has created for you (the faculties of) hearing, sight, feeling and understanding little thanks it is ye give!" (Qur'an, 23:78), and (2) things that are entrusted to us by our fellow human beings (huquq al-Nas - the rights of the people) such as wealth and secrets which shouldn't be revealed to others. Allah commands that we should render back the trusts to those to whom they are due (Qur'an, 4:58) and He warns us of transgression, betrayal or violation of lamanah (Qur'an, 8:27).

It is worth noting that: first, there is a deep relationship between amanah and iman, meaning that without fulfilment of amanah, iman is invalid. Anas ibn Malik (may Allah be pleased with him) reported: The Messenger of Allah (PBUH) said, "There is no faith (iman) for one who cannot be trusted (la amanata lahu). There is no religion for one who cannot keep a promise." (Ibn Hanbal (Ahmad), 11975, Sahih). Here it is evident that fulfilment of amanah is a necessary requirement for validation of iman. Narrated by Abu Hurayrah (may Allah be pleased with him): The Prophet (PBUH) said, "Whoever believes in Allah and the Last Day, should not hurt his neighbour and whoever believes in Allah and the Last Day, should serve his guest generously and whoever believes in Allah and the Last Day, should speak what is good or keep silent." (Al-Bukhari, 6136, Sahih). In this hadith the Prophet (PBUH) instructs us to honour the amanat or rights of our neighbour(s), guest(s) and tongue. In other words, he enjoins us to fulfil our responsibilities towards all these. Therefore, it should be borne in mind that there is a correlation between huquq (rights) and wajibat (duties), meaning the two are closely related and cannot be separated from one another. Second, the root word of amanah is amn, which means that there is a mutual relationship between iman, amanah and amn.

\section{Al-Istiqamah}

Al-Istiqamah is promptness and steadfastness in fulfilling amanat (Allah's commands). A sincere believer in Allah is always increasing or constant in doing good deeds but not dwindling. Allah says (interpretation of the meaning): "But, without doubt, I am (also) He that forgives again and again, to those who repent, believe, and do right, who, in fine, are ready to receive true guidance (thumma ihtada)." (Qur'an, 20:82). Thumma ihtada is also translated as "and thereafter keeps to the right path" (Muhammad Asad) or "then persists on true guidance" (Mustafa Khattab). The Arabic concept for thumma ihtada is al-Istiqamah (firmness and steadfastness). On the authority of Abu 'Amr - and he is also mentioned as Abu 'Amrah - Sufyan bin 'Abdu'llah, who said: I said, "O Messenger of Allah, tell me something about Islam which I will not [need to] ask anyone but you." He said, "Say, 'I believe in Allah,' and then remain upright." (Al-Nawawi, 21, Sahih). 


\section{Moral Attributes}

Allah created mankind to live a moral life. He says (interpretation of the meaning):

"Behold, thy Lord said to the angels: "I will create a vicegerent on earth." They said: "Wilt Thou place therein one who will make mischief therein and shed blood? whilst we do celebrate Thy praises and glorify Thy holy (name)?" He said: "I know what ye know not."” (Qur'an, 2:30).

"Generations before you We destroyed when they did wrong: their apostles came to them with clear-signs, but they would not believe! thus do We requite those who sin! Then We made you heirs in the land after them, to see how ye would behave!" (Qur'an, 10:13-14).

It is evident from these verses that Allah did not create human beings to shed blood (kill each other due to insatiable greed, envy, hatred, etc.) and spread mischief in the land (on Earth), but to live according to moral standards. He also says (interpretation of the meaning):

"O mankind! We created you from a single (pair) of a male and a female, and made you into nations and tribes, that ye may know each other (not that ye may despise (each other) lita'arafu. Verily the most honoured of you in the sight of Allah is (he who is) the most righteous of you. And Allah has full knowledge and is well acquainted (with all things)." (Qur'an, 49:13).

It is clear from this verse that: first, nobility does not lie in one's race, ethnicity, ancestry or gender. True nobility lies in being submissive to Allah; bowing down and prostrating to Him, doing what He has commanded and avoiding what He has forbidden; second, ta'aruf is the reason for gender binary and ethnic and racial diversity. It is also the basis of human relationships and interaction with one another.

Lita'arafu, is an Arabic verb with variant meanings, including but not limited to the following:

1) To build relationships of brotherly love and affection.

2) To appreciate each other's cultural differences which are in agreement with alShari'ah (Divine Law).

3) To understand and recognize the physical appearance of other ethnicities and behave sensibly with them.

4) To acknowledge the contributions of diverse groups.

5) To lend aid and support to others, or in other words, to strengthen each other, care for each other and defend each other.

6) To treat one another with full dignity and honour.

7) To bring about unity through diversity.

8) To live side by side peacefully, orderly and harmoniously.

9) To enjoin each other to do what is virtuous and abstain from what is vicious.

10) To collaborate and cooperate with each other.

11) To accept and honour the natural or factual differences.

12) To share knowledge and pass it to future generations.

Cooperation is an act of working together or helping each other out to achieve a common purpose, benefit or goal, instead of working separately in competition. Allah says (interpretation of the meaning): "Help ye one another in righteousness and piety, but help ye not one another in sin and rancour: fear Allah. for Allah is strict in punishment." (Qur'an, 5:2). Throughout history, humanity has depended on one another, cooperated with each other and learnt from one another. Competition with the goal to dominate, personal ambition, nationalism, self-interest, selfishness and greed are antithesis of cooperation. They promote conflict and divide people. 
Prophet Muhammad (PBUH) described moral virtues as the "best thing given to man" and a Muslim with the "perfect faith" as the one "who has the best moral character." 'Abdu'llah bin 'Amr bin Al-'As (may Allah be pleased with them) reported: The Prophet (PBUH ) said, "A Muslim is the one from whose tongue and hands the Muslims are safe; and a muhajir (emigrant) is the one who refrains from what Allah has forbidden." When he was asked: Who amongst the slaves of Allah is the dearest to Him? The Prophet (PBUH) replied: "One who has the best moral character." Based on these and many other hadith on good moral character one can infer that the beauty of a Muslim and his nobility is in the goodness of his character. Good manners illuminate one's life and makes it attractive to others.

Allah praises the Prophets (peace be upon them) based on their spiritual, moral and intellectual virtues. For example, He praises the Prophet Muhammad (PBUH) for his submissiveness to Him (Qur'an, 3:20 \& 6:163), purity in worship (Qur'an, 10:104), faith in Him and His words (Qur'an, 7:158), devotion to Him (Qur'an, 73:20\&48:29), mercy to all the inhabitants of the world (Qur'an, 21:107), kindness and mercy to the believers (Qur'an, 9:128), gentleness to the people (Qur'an, 3:159), deep concern for the people (Qur'an, 9:128), taqwa (God-fearing) (Qur'an, 39:13), trust in Him (Qur'an, 42:10); Ibrahim for his righteousness (Qur'an, 2:130), submission to Him (Qur'an, 2:131), uprightness (Qur'an, 3:67, 16:120,123, 6:161, 6:79, 4:125\&3:95), beneficence (Qur'an, 37:105), tender-heartedness and forbearance (Qur'an, 9:114 \& 11:75), patience (Qur'an, 11:75), obedience (Qur'an, 16:120), gratefulness (Qur'an, 16:121), pure-heartedness (Qur'an, 37:84) and faithfulness (Qur'an, 37:111), among others; 'Isa for his righteousness (Qur'an, 6:85\&3:46), nearness to Him (Qur'an, 3:45) and purity (Qur'an, 19:19), among others; Musa for his patience and faithfulness (Qur'an, 7:143), purity (Qur'an, 19:51), beneficence (37:121), nobility (Qur'an, 44:17) and trustworthiness (Qur'an, 44:18); Yusuf for his truthfulness (Qur'an, 12:46), trustworthiness (Qur'an, 12:54) and beneficence (Qur'an, 12:56), among others; Yunus for his glorification of Him (Qur'an, 37:143), Lut for his trustworthiness (Qur'an, 26:162) and righteousness (Qur'an, 66:10), among others; Salih for his trustworthiness (Qur'an, 26:143); Dawud for his penitence (Qur'an, 38:17); Harun for his beneficence (Qur'an, 37:121) and faithfulness (Qur'an, 37:122); Nuh for his trustfulness in Him (Qur'an, 10:71), gratefulness (Qur'an, 17:3), trustworthiness (Qur'an, 26:107), beneficence (Qur'an, 37:80), faithfulness (Qur'an, 37:81) and righteousness (Qur'an, 66:10); Sulaiman for his penitence (Qur'an, 38:30); Yahya for his eminence, chastity and righteousness (Qur'an, 3:39), compassion, purity and piousness (Qur'an, 19:13), and obedience (Qur'an, 19:14), among others; llyas for his righteousness (Qur'an, 6:85); Hud for his trust in Him (Qur'an, 11:56) and trustworthiness (Qur'an, 26:125); Shu'ayb for his penitence (Qur'an, 11:88) and trustworthiness (Qur'an, 11:87); Ya'qub for his trust in Him (Qur'an, 12:67) and righteousness (Qur'an, 21:72); Isma'il for his submissiveness to Him (Qur'an, 37:103), truthfulness in promise (Qur'an, 19:54) and patience (Qur'an, 37:101-102); Ishaq for his righteousness (Qur'an, 21:72\&37:112); and Zakariyya for his humbleness before Him (Qur'an, 21:90).

He describes the Muslim nation as a nation characterized by iman billāh (faith in Allah) and moral virtues: "Ye are the best of peoples, evolved for mankind, enjoining what is right, forbidding what is wrong, and believing in Allah. If only the People of the Book had faith, it were best for them: among them are some who have faith, but most of them are perverted transgressors." (Qur'an, 3:110). It is understood from this verse that the strength of a nation derives from its iman billah (having faith and trust in Allah) and makarim al-Akhlaq (high moral standards or values), not in supertall and megatall buildings. 
Shawqi (1868 - 1932), "the amir al-Shu'ara' (prince of poets) of modern Arabic poetry and a pioneer of Arabic poetical drama," remarked, innama al-'Umam al-Akhlaq ma baqiyat, fa in hum dzahabat akhlaquhum dzahabu, meaning "nations are strong with their morals, if these morals are gone, they are gone (their strength is lost)."

Over the past several decades, cases of immorality have grown into major social problems which have ruined the lives of many young people and imposed heavy costs on families, organizations and governments. This has been attributed to the absence of soul. Moore writes:

"The great malady of the twentieth century, implicated in all of our troubles and affecting us individually and socially, is "loss of soul. When soul is neglected, it doesn't just go away; it appears symptomatically in obsessions, addictions, violence, and loss of meaning." (Moore, $1992, x i)$.

Al-Qaradawi describes the present-day civilization as materially well-developed but spiritually bankrupt:

"As a matter of fact, present-day civilization provides humanity with unparalleled and unprecedented means of luxury and comfort. Unfortunately, this civilization pays no attention to the human nature, characteristics, future or prosperity. On the contrary, it is a source of trouble and danger to humanity" (Al-Qaradawi, 1998).

\section{Intellectual Attributes}

Intellectual attributes are qualities of mind and character such as tadabbur and tafakkur (reflection). These terms denote "having e a broader view," that is, to look beneath the surface of things, including looking beyond this transient life of dunya (the physical world) or having a glimpse of al-Akhirah (the Hereafter world), pondering over the ill effects of one's bad manners, and to look deeper into the text for a deeper understanding, which is specifically called tafaqquh; ta'aqqul (reasoning critically and creatively; avoidance of blind imitation); tadhakkur (remembrance); tasawwur (perception); tabyin (clarification); tamyiz (discernment or differentiating right from wrong) and fahm (comprehension of the meaning of things). Allah says (interpretation of the meaning):

"(We sent them) with Clear Signs and Books of dark prophecies; and We have sent down unto thee (also) the Message; that thou mayest explain clearly to men what is sent for them, and that they may give thought." (Qur'an, 16:44).

"(Here is) a Book which We have sent down unto thee, full of blessings, that they may mediate on its Signs, and that men of understanding may receive admonition." (Qur'an, 38:29).

"Thus doth Allah Make clear His Signs to you in order that ye may understand." (Qur'an, 2:242).

"And We have indeed made the Qur'an easy to understand and remember: then is there any that will receive admonition?" (Qur'an, 54:17, 22, 32, 40).

The terms used in the Qur'an to describe people who possess the above-mentioned attributes are 'ulu al-Albab (men of understanding) and qawmun ya'qilun (people who use their intellect). Here it should be noted that intellect is the inner sense, the Divine light that illuminates the heart, a guide in one's heart, the basis of taklif (the commandment to act in accordance with Allah's orders or the basis of accountability in this world and in the hereafter) and the faculty by which Allah has favoured humans over other creatures. It is, therefore, the source of human honour and virtue. 


\section{Means to Attain Godliness}

There are three steps to godliness: first, to find an answer to the questions "who am I?" and "Who is my Creator?" This is termed as "self-knowledge" or "the self-concept." Second, to find an answer to the question "why am I here?" or "what is the reason for my existence?" Third, to find an answer to the question "what are the must do's to fulfil the purpose of my existence?" The aim of revelation is to answer these big questions of life.

\section{Attainment of Godliness through Knowledge Acquisition}

Having knowledge of the following is essential to godliness: (1) knowledge of Allah and His rights; (2) knowledge of purification and perfection of self; (3) knowledge of the rights of others and one's duties to them; (4) knowledge of reward and punishment of one's actions; (5) and knowledge of the manners of the Prophets (peace and blessings be upon them). The first command of Allah to Prophet Muhammad (PBUH) and his ummah (nation) is iqra' (read!), which means, "learn or seek knowledge:"

"Proclaim! (or read!) in the name of thy Lord and Cherisher, Who created. Created man, out of a (mere) clot of congealed blood. Proclaim! And thy Lord is Most Bountiful. He Who taught (the use of) the pen. Taught man that which he knew not." (Qur'an, 96:1-5).

These verses highlight the following fundamental issues:

1. Reading in the Name of Allah, the Creator, the Most Bountiful, and the Teacher of Mankind.

2. Allah's Qudrah (ability) to create "a worthy creature," that is, a human being, from "a lowly unworthy thing," namely al-'Alaq (a clot of congealed blood).

3. Allah's extreme and extraordinary generosity.

4. The value of pen and the worth of knowledge.

From the above verses we can deduce the following: first, the quest for knowledge, its application and dissemination ought to be God (Allah)-centered. This is because knowledge extends from Allah for the purpose of guiding mankind to Him (Allah).

In Islam Allah is acknowledged as the Ultimate Source of all knowledge and guidance. With Him lies all the treasures of knowledge. He is the Teacher of mankind; the One Who has inspired them to learn and provided them with the senses and the intellect - the power of understanding and contemplation or the ability to come to correct conclusions about what is right or wrong - as means of discovering and knowing the reality. He says (interpretation of the meaning):

"It is He Who brought you forth from the wombs of your mothers when ye knew nothing; and He gave you hearing and sight and intelligence and affections: that ye may give thanks (to Allah." (Qur'an, 16:78).

"Say: "Think ye, if Allah took away your hearing and your sight, and sealed up your hearts, who - a god other than Allah - could restore them to you?" See how We explain the signs by various (symbols); yet they turn aside." (Qur'an, 6:46).

Second, acquisition of knowledge of Allah (ma'rifatu'llah) and knowledge of self (ma'rifat alNafs) is Man's foremost duty. Allah says (interpretation of the meaning):

"Know, therefore, that there is no god but Allah, and ask forgiveness for thy fault, and for the men and women who believe: for Allah knows how ye move about and how ye dwell in your homes." (Qur'an, 47:19).

"...Those truly fear Allah, among His Servants, who have knowledge: for Allah is Exalted in Might, Oft-Forgiving." (Qur'an, 35:28). 
It is clear from the meanings of these verses that ma'rifatu'llah (knowledge of Allah) precedes shahadatu alla ilaha illa Allah (declaration of belief in the indivisible oneness of Allah), istighfar (the act of seeking forgiveness from Allah) and taqwa (consciousness or fear of Allah and getting closer to $\mathrm{Him}$ ).

Knowing oneself or self-knowledge means to be aware of: first, one's origin (creation) and the purpose of one's creation or one's duties (what has been made obligatory on a person) or the relationship between a person and his Creator; and second, the soul and body diseases and their remedies. The importance of self-knowledge is highlighted in the following verse:

"Soon will We show them our Signs in the (furthest) regions (of the earth), and in their own souls, until it becomes manifest to them that this is the Truth. Is it not enough that thy Lord doth witness all things?" (Qur'an, 41:53).

According to this verse, the signs of Allah's existence are clear and they are located in two places, namely within one's own self and within the universe. Hence, it is a duty of all human beings to observe them in order to recognize their Creator or to arrive at a state of yaqin (certainty) in iman (faith). Allah says (interpretation of the meaning): "On the earth are signs for those of assured Faith, as also in your own selves: Will ye not then see?" (Qur'an, 51:2021). From this verse it is understood that the creation of the universe was not coincidental, but rather it is the greatest proof for the existence and Lordship of Allah. Allah says (interpretation of the meaning):

"Behold! in the creation of the heavens and the earth, and the alternation of night and day, there are indeed Signs for men of understanding. Men who celebrate the praises of Allah, standing, sitting, and lying down on their sides, and contemplate the (wonders of) creation in the heavens and the earth, (With the thought): "Our Lord! not for naught Hast Thou created (all) this! Glory to Thee! Give us salvation from the penalty of the Fire."' (Qur'an, 3:190-191). "Do they not reflect in their own minds? Not but for just ends and for a term appointed, did Allah create the heavens and the earth, and all between them: yet are there truly many among men who deny the meeting with their Lord (at the Resurrection)!" (Qur'an, 30:8).

These are some of the other verses indicating clearly that the universe did not appear arbitrarily for no reason, but rather it is Allah's creation to be reflected upon so as to recognize and acknowledge His existence and Lordship as mentioned in the foregoing. It is worth noting that many Muslim scholars described knowledge of Allah as "a light within the heart." For example, Imam Malik said, "Knowledge is not knowing many sayings. Verily, knowledge is only a light that Allah places in the hearts." ('Iyadh (al-Qadhi), 1970, p. 217). Ibn Rajab also said, "Knowledge is not memorizing many narrations or sayings, but rather it is a light that Allah places in the heart by which a servant understands the truth and he distinguishes it from falsehood." (Ibn Rajab \& Ajmai. 1995, p. 58).

It is also worth mentioning that knowledge of one's origin leads to knowledge of one's Creator: "Man 'arafa nafsahu faqad 'arafa Rabbahu - Whosoever knows himself knows his Lord." This saying, which is attributed to Abu Zakariyya Yahya ibn Mu'adh al-Razi (830-871 A.D.), can be interpreted to mean self-knowledge is about being aware of one's Creator (Allah), which also means that the ultimate goal of self-knowledge or knowledge of the self is knowledge of Allah: "I have only created Jinns and men, that they may serve Me (illa liya 'budun)." (Qur'an, 51:56). The famous Quran interpreter (mufassir), 'Abdu'llah ibn 'Abbas, interpreted the words "that they may serve Me (illa liya 'budun)" as "that they may know Me (illa liya'rifuni)." The same interpretation was offered by Mujahid and many others. (AlBaghawi, 2010, vol. 4, p. 235 \& Chittick, 1989, p.150). 
Knowledge of Allah and knowledge of the self are the prerequisite and the basis of 'ibadah, one's devotion to Allah. How can one perform 'ibadah to Allah, love and appreciate Him without knowing Him!

Third, 'ibadah is an expression of love and gratitude to Allah. He is al-Rabb, the Creator (of everything), and al-Akram, the "Most Bountiful," "He Who taught (the use of) the pen," and He has "taught man that which he knew not!" Expressing gratitude to Allah means: first, acknowledgement of His bounties. Allah says (interpretation of the meaning): "For Allah is full of bounty to mankind, but Most of them are ungrateful." (Qur'an, 2:243). He also says: "And He giveth you of all that ye ask for. But if ye count the favours of Allah, never will ye be able to number them. Verily, man is given up to injustice and ingratitude." (Qur'an, 14:34). Second, humbling oneself before Him by doing what He has commanded, avoiding what He has prohibited and accepting what He has ordained. Third, praising and glorifying Him. Last, loving Him more than anything or anyone else. He says (interpretation of the meaning):

"Say: If it be that your fathers, your sons, your brothers, your mates, or your kindred; the wealth that ye have gained; the commerce in which ye fear a decline: or the dwellings in which ye delight - are dearer to you than Allah, or His Messenger, or the striving in His cause; then wait until Allah brings about His decision: and Allah guides not the rebellious." (Qur'an, 9:24). Loving Allah is the only thing which makes a person obey Him and draw closer to Him by doing what He has commanded, avoiding what He has prohibited and accepting what He has ordained.

Fourth, knowledge is one of the favours and graces of Allah upon mankind. While The Bible opens with the statement "In the beginning God created the heavens and the earth" (Genesis 1 New International Version (NIV)), the Qur'an begins with the command to seek knowledge. Fifth, reading is one of the means to ma'rifatullah, the knowledge of Allah, meaning it is trough reading that we get to know Allah. The command: "Read" is a great honour to knowledge. It indicates that valid knowledge is from Allah for the purpose of guiding mankind to the right beliefs and practices.

Sixth, what is commanded to us to read is the Divine Revelation, meaning the Qur'an, the Book of guidance. Islam has commanded its followers to read from cradle to the grave. In other words, it has made the pursuit of knowledge a life-long endeavour.

Seventh, of all the knowledge we can gain, the most important is the knowledge of Allah, oneself and the purpose of life. All the knowledge we acquire will not be praiseworthy unless we know Allah, ourselves and the reason why we are here. Hence, it is incumbent upon every human being to acquire knowledge of these three.

Eighth, human beings ought to begin their actions by mentioning Allah's Name to indicate: (1) dzikr Allah (remembrance of Allah or God-consciousness): "Then do ye remember Me; I will remember you. Be grateful to Me and reject not Faith." (Qur'an, 2:152); (2) isti'anah (the need for Allah's help and protection): "Thee do we worship, and Thine aid we seek." (Qur'an, 1:5); and (3) Ikhlas (sincere devotion to Allah): "And they have been commanded no more than this: To worship Allah, offering Him sincere devotion, being true (in faith); to establish regular prayer; and to practise regular charity; and that is the Religion Right and Straight." (Qur'an, 98:5). The following are the common statements upon performing an action: A'udzu billahi mina al-Shaitani al-Rajim (I seek refuge in Allah from the accursed Satan); Bismi'llahi alRahman al-Rahim (In the name of Allah, Most Gracious, Most Merciful); and Alhamdulillahi Rabbi al-'Alamin (Praise be to Allah, the Cherisher and Sustainer of the worlds).

Ninth, the instruction to read in the Name of Allah, the Creator, the Most Bountiful, and the Teacher of Mankind means, among others: (1) acknowledgement and recognition of the 
existence of the Creator (Allah) and His creative power. The main objective of reading or acquisition of knowledge in Islam is acknowledgment and recognition of Allah as the Creator, the Benevolent and the Teacher of Mankind; (2) acknowledgement and recognition of Allah's benevolence and be grateful for it. According to the following verses, Allah's blessings to mankind are immeasurable but most of mankind are ungrateful to Allah; instead of showing obedience to Him, they transgress His limits; they boast about their achievements; they do not recognize Allah as the Source of their strength (material achievements), knowledge (intellectual achievements), livelihood and success. Allah draws mankind's attention to His favours, gifts and blessings. He says (interpretation of the meaning):

"If ye would count up the favours of Allah, never would ye be able to number them, for Allah is Oft-Forgiving, Most Merciful." (Qur'an, 16:18).

"It is He Who gave you life, will cause you to die, and will again give you life: Truly man is a most ungrateful creature!" (Qur'an, 22:66).

"And He giveth you of all that ye ask for. But if ye count the favours of Allah, never will ye be able to number them. Verily, man is given up to injustice and ingratitude." (Qur'an, 14:34).

"It is He Who has created for you (the faculties of) hearing, sight, feeling and understanding: little thanks it is ye give!" (Qur'an, 23:78. See also 100:6, 2:243, 7:10, 7:17, 10:60, 14:34 \&17:67).

In Jahiliyyah or the age of ignorance, which is the period preceding the revelation of the Qur'an to the Prophet Muhammad (PBUH), the Arabs acknowledged and recognized Allah as the Creator and Sustainer: "If thou ask them, who it is that created the heavens and the earth. They will certainly say, "Allah". Say: "Praise be to Allah!" But most of them understand not." (Qur'an, 31:25). Nevertheless, instead of being grateful and dutiful to Him, they worshipped idols and transgressed the limits He set for them. Hence, one of the aims of revelation is to convey that acknowledgment and recognition of Allah as the Creator and Sustainer necessitates thanksgiving and glorification, meaning sincere devotion to Him and respect of the limits He set for mankind: "Those are limits set by Allah. Those who obey Allah and His Messenger will be admitted to Gardens with rivers flowing beneath, to abide therein (forever) and that will be the supreme achievement." (Qur'an, 4:13).

Tenth, Iqra' is a polysemous concept. It means to 'read,' 'understand,' 'observe,' 'reflect,' and 'apply.' This is especially true in the case of the Qur'an. It was revealed: (1) to be read correctly, meaning according to the way it was revealed to the Prophet Muhammad (PBUH). In order to read the Qur'an correctly, a Muslim is required to first acquire 'ilm al-Tajwid (knowledge of the Arabic alphabet, their phonetic sounds, and the significance of the different kinds of pauses used in the Qur'an); (2) to be understood and pondered over; (3) to be the medium through which Allah is remembered (4) and to be the ultimate moral guide for mankind. Therefore, when reading or listening to the Qur'an, a Muslim should ask himself (introspection and self-examination) the following questions: "Where am I in regard to this ayah (verse or sign of Allah)?" "Do I understand its meaning or message? "Do I practice what I know? Or "Do I act as a living example of the Qur'an?" "What problems stand in the way of implementing this ayah (verse)? This is called tadabbur al-Qur'an (reflection on the Qur'an). Many Muslims devote their time to tilawah (reading the Qur'an) but only a few endeavor to understand its meaning or message. According to Israr Khan, "it is possible that the punishment for ignoring the meaning and message of the Qur'an may exceed the reward for reciting its text." (Ahmad, 2005, p.24).

Eleventh, the One Who created Man, acquainted him with reading and writing (taught him the use of pen and all what he knows) is the only God worthy of appreciation or worship: "O 
ye people! Adore your Guardian-Lord, who created you and those who came before you, that ye may have the chance to learn righteousness." (Qur'an, 2:21); "Is then He Who creates like one that creates not? Will ye not receive admonition?" (Qur'an, 16:17).

Twelfth, the instruction to read is repeated twice to emphasize the importance of reading in Man's life. Reading or literacy is the key to success. Valliani writes, Muslims' "intellectual development owes much to their reading and reflection." (Valliani, January 3, 2014). Reading enables us to travel into the past in order to awaken our inner faculty, that is, the intellect or the power of thought, imagination, memory, reflection and comprehension, and to understand our past or the past events which in turn contributes to our knowledge of the present. Allah says (interpretation of the meaning):

"Has there not been over Man a long period of Time, when he was nothing - (not even) mentioned? Verily We created Man from a drop of mingled sperm, in order to try him: So We gave him (the gifts), of Hearing and Sight." (Qur'an, 76:1-2).

"This is because of the (unrighteous deeds) which your hands sent on before ye: For Allah never harms those who serve Him." (Qur'an, 3:182).

Thirteenth, the act of reading that we are invited to acquire is the ability to see the signs of Allah within ourselves and within universe:

"Soon will We show them our Signs in the (furthest) regions (of the earth), and in their own souls, until it becomes manifest to them that this is the Truth. Is it not enough that thy Lord doth witness all things?" (Qur'an, 41:53).

"Behold! in the creation of the heavens and the earth, and the alternation of night and day, there are indeed Signs for men of understanding. Men who celebrate the praises of Allah, standing, sitting, and lying down on their sides, and contemplate the (wonders of) creation in the heavens and the earth, (With the thought): "Our Lord! not for naught Hast Thou created (all) this! Glory to Thee! Give us salvation from the penalty of the Fire."'" (Qur'an, 3:190-191). The universe is described as "the visible book of Allah": "The universe itself is a gigantic, cosmic book having divine signs to be read, reflected on, ruminated and comprehended. One can also read the human face or natural phenomenon appearing in time and space. This leads one to discover possible future trends and happenings." (Valliani, January 3, 2013).

Allah describes those who fail to utilize their intellect to ponder over His signs; those who fail to realize the wisdom behind His creation as follows: "They know but the outer (things) in the life of this world: but of the End of things they are heedless." (Qur'an, 30:7).

Fourteenth, the Qur'anic concept Iqra' which is translated as "Read!" is not restricted to the act of reading from a written text. It also refers to recitation from memory: "at the time of the revelation, there was no written text in sight. This gives us an idea that reading is not limited to written, printed or electronic text, but includes unwritten text spread all around." (Valliani, January 3, 2013).

The Prophet (PBUH) was unlettered, which means he could not read from a written book yet as indicated in the following verses, he could read from memory:

"When thou (Muhammad) dost recite the Qur'an, We put, between thee and those who believe not in the Hereafter, a veil invisible" (Qur'an, 17:45).

"It is He Who has sent amongst the Unlettered an apostle from among themselves, to rehearse to them His Signs, to sanctify them, and to instruct them in Scripture and Wisdom, although they had been, before, in manifest error" (Qur'an, 62:2).

Fifteenth, pen and knowledge are part of the greatest blessings of Allah bestowed upon Mankind. They are the basis of their development and progress. With the help of pen, knowledge is taught and transferred from one generation to another. 
Sixteenth, Allah has singled out Mankind for mention because the Qur'an was revealed to them. They are the khulafa' al-Ardh (trustees or guardians of the earth) and therefore, "the most intelligent and wise among living creatures":

"Behold, thy Lord said to the angels: "I will create a vicegerent on earth." They said: "Wilt Thou place therein one who will make mischief therein and shed blood? whilst we do celebrate Thy praises and glorify Thy holy (name)?" He said: "I know what ye know not." (Qur'an, 2:30).

Seventeenth, Allah draws Man's attention to the way he was created, and He also reminds him again and again of the lowly and inferior thing from which He created him so that he may acknowledge His Creator and humble himself:

"Now let man but think from what he is created! He is created from a drop emitted. Proceeding from between the backbone and the ribs." (Qur'an, 86:5-7).

"It is He Who has created you from dust then from a sperm-drop, then from a leech-like clot; then does he get you out (into the light) as a child: then lets you (grow and) reach your age of full strength; then lets you become old, though of you there are some who die before; and lets you reach a Term appointed; in order that ye may learn wisdom." (Qur'an, 40:67).

"Man We did create from a quintessence (of clay); then We placed him as (a drop of) sperm in a place of rest, firmly fixed; then We made the sperm into a clot of congealed blood; then of that clot We made a (foetus) lump; then we made out of that lump bones and clothed the bones with flesh; then we developed out of it another creature. So blessed be Allah, the best to create!" (Qur'an, 23:12-14).

"Doth not man see that it is We Who created him from sperm? yet behold! he (stands forth) as an open adversary! And he makes comparisons for Us, and forgets his own (origin and) Creation: He says, "Who can give life to (dry) bones and decomposed ones (at that)?"” (Qur'an, 36:77-78).

Eighteenth, reading is the key to enlightenment, that is, the liberation of the human mind from blind imitation or suppositions. Hence, one may date the beginning of enlightenment in the Islamic outlook to the first revelation.

Last but not least, Man owes his knowledge and achievements to Allah. He is the One Who taught him the use of pen or the act of writing and the names of things. He created in him the media through which he receives knowledge, namely the senses and the faculty of reason. Additionally, He sent to him Divine revelation to illuminate his faculty of reason, among others. He sent to him Divine revelation to illuminate his faculty of reason, among others. He says, which means:

"Behold, thy Lord said to the angels: "I will create a vicegerent on earth." They said: "Wilt Thou place therein one who will make mischief therein and shed blood whilst we do celebrate Thy praises and glorify Thy holy (name)?" He said: "I know what ye know not." And He taught Adam the nature of all things; then He placed them before the angels, and said: "Tell me the nature of these if ye are right." They said: "Glory to Thee, of knowledge We have none, save what Thou Hast taught us: In truth it is Thou Who art perfect in knowledge and wisdom." He said: "O Adam! Tell them their natures." When he had told them, Allah said: "Did I not tell you that I know the secrets of heaven and earth, and I know what ye reveal and what ye conceal?" And behold, We said to the angels: "Bow down to Adam" and they bowed down. Not so Iblis: he refused and was haughty: He was of those who reject Faith." (Qur'an, 2:3034). 
From this verse the following can be deduced

First, knowledge is the greatest treasure, blessing and the highest dignity endowed by Allah to mankind. It is the torch that illuminates their life; the requisite for the fulfilment of their physical and spiritual needs.

Second, human's dignity resides in his rational nature and is earned by knowledge. With knowledge man gains control over nature, he develops the earth, and he is set apart from the other creatures.

Third, ignorance - the absence of knowledge - is the cause of mischief and bloodshed. Abu Hurayrah (may Allah be pleased with him) reported Allah's Messenger (PBUH) as saying: "(When) the time would draw close to the Last Hour, knowledge would be snatched away, turmoil would be rampant, miserliness would be put (in the hearts of the people) and there would be much al-Harj. They said: What is al-Harj? Thereupon he said: It is bloodshed." (AlNisaburi, 6459, Sahih).

Fourth, not only that Allah honoured Adam with knowledge but He also honoured him with the highest position on the earth. He made him khalifat al-Ardh - the successor of this Earth or its developer; He gave him and his posterity the authority over all creatures on the earth; He made the Earth and all that it contains subservient to him. In other words, He bestowed upon him the highest respect. He says (interpretation of the meaning):

"Seest thou not that Allah has made subject to you (men) all that is on the earth, and the ships that sail through the sea by His Command? He withholds the sky (rain) from failing on the earth except by His leave: for Allah is Most Kind and Most Merciful to man." (Qur'an, 22:65). Fifth, possession of knowledge is a requirement of khilafah, leadership or human custodianship of the earth.

"The gauge for the progress and civilization of any nation is the quality and the number of books and the number of persons habituated of reading them. Formal education of a person is no criterion of judging a person's learning. A really learned person is one who is engaged in meaningful reading and research." (https://www.al-islam.org/principles-upbringing-childrenayatullah-ibrahim-amini/chapter-72-habit-reading-books).

Sixth, the history of human knowledge begins with Adam (peace be upon him) and it can only be described based on the above verse.

Seventh, Allah is the Ultimate Source of knowledge. He is the One and the only who teaches man everything. He is the Teacher and Absolute Guide of all creatures: "(When this message was delivered), (Pharaoh) said: "Who, then, O Moses, is the Lord of you two?" He said: "Our Lord is He Who gave to each (created) thing its form and nature, and further, gave (it) guidance."'" (Qur'an, 20:49-50). The angels witnessed the reality that Allah is Al-'Alim, The AllKnowing, Al-Hakim, The Wise.. They said: "Glory to Thee, of knowledge We have none, save what Thou Hast taught us: In truth it is Thou Who art perfect in knowledge and wisdom." This notion, that is, that Allah is the Ultimate Source of knowledge, is also held by the Judaists and Christians: "He Who disciplines and instructs the nations, shall He not punish, He Who teaches man knowledge?" (Psalm 94:10).

\section{Attainment of Godliness through 'Ibādāt (Islamic Rituals)}

Allah commanded salat, zakat, sawm (fasting) and hajj as pillars of Islam with the aim to purify the hearts of human beings as is evident in the verses below:

"Recite what is sent of the Book by inspiration to thee, and establish regular Prayer: for Prayer restrains from shameful and unjust deeds; and remembrance of Allah is the greatest (thing in life) without doubt. And Allah knows the (deeds) that ye do." (Qur'an, 29:45). 
"Of their goods, take alms, that so thou mightest purify and sanctify them; and pray on their behalf. Verily thy prayers are a source of security for them: And Allah is One Who heareth and knoweth." (Qur'an, 9:103).

"O ye who believe! Fasting is prescribed to you as it was prescribed to those before you, that ye may (learn) self-restraint." (Qur'an, 2:183).

"For Hajj are the months well known. If anyone undertakes that duty therein, let there be no obscenity, nor wickedness, nor wrangling in the Hajj. And whatever good ye do, (be sure) Allah knoweth it. And take a provision (With you) for the journey, but the best of provisions is right conduct. So fear Me, o ye that are wise." (Qur'an, 2:197).

Here it is understood that salat, zakat, sawm (fasting) and hajj are stepping stones to righteousness. Salat is an act of reverence, gratitude and total submission to Allah. It prevents a person from obscenity and shameful activities, and it is also a means to punctuality, cleanliness and purity of the heart; it purifies the heart from spiritual diseases such as arrogance and makes a person humble; zakat is an act of kindness, sympathy and benevolence. It cleanses the self of greed, selfishness and envy; sawm abstains from wicked and obscene things and adorns the heart with patience, generosity and many other spiritual virtues; and hajj is a symbol of Muslim unity, brotherhood, cooperation, affection and humility. It adorns the heart with patience and abstains from immoral acts and disputes.

The above indicates that moral values ought to be an integral part of a person's beliefs and practices. Malik (may Allah be pleased with him) reported: The Messenger of Allah (PBUH) said: "I have been sent to perfect good character." (Ibn Anas (Malik), 1614, Sahih).

\section{Conclusion}

In this paper we have described the spiritual, moral and intellectual attributes of a godly person. From the aforesaid it follows that: first, a godly person is one whose life is devoted to Allah; he is obedient to Him (he performs what He has commanded and abstains from what He has forbidden), lives an orderly life, modest and humble, generous, just, honest, patient, gentle to the people, fulfils the amanah, sympathetic, kind and merciful to all living creatures on Earth, abstains from moral indecency and whatever is incompatible with human dignity, and he enjoins good and forbids wrong, among others; second, iman and amanah have the same etymology. Both are derived from amn, which means peace, safety and tranquillity that Allah causes to descend upon the hearts of His slaves who have iman (faith in Him) and fulfil the amanat (moral responsibilities); third, good manners are not limited to visible actions or actions of the limbs, but they are also in inner self. The inner self is where good manners are established and it is from there that they proceed; fourth, godliness is reached through knowledge of the rights of Allah, oneself and others, and acting upon it (knowledge); fifth, knowledge is so important that Allah began His final revelation to mankind by commanding them to "read" and introducing Himself as the "Giver of knowledge;" the One Who taught Man the use of pen, taught him what he knew not; sixth, the reason for creating human beings and Jinns is 'ibadat Allah, which means, recognition of Allah and subsequent submission or humility and obedience to Him.

Finally, it is hoped that the information and knowledge gained from this study will contribute to a better understanding of the Islamic perspective of godliness especially with regard to the following: first, the Islamic perspective of godliness and the Islamic educational institutions' mission to develop godly individuals to contribute significantly to moral, spiritual and physical welfare of humanity in general, and bring back the past glory and fame of the ummah (Muslim community) in particular; second, God-centered education; third, iqra' as the key to godliness 
and ta'aruf as the reason for gender binary, ethnic and racial diversity, and the basis of human relationships and interaction with one another; and last but not least, the interpretation of the first revelation to Prophet Muhammad (PBUH). There are nineteen interpretations of the first revelation offered in this study which are considered as the key characteristics of Godcentered education or curriculum.

\section{References}

AbdurRahman.org. (2014). "Sincerity in seeking knowledge is a condition that is continuous and not just preliminary - Shaykh Muhammad Baazmool". https://abdurrahman.org/2014/09/30/sincerity-in-seeking-knowledge-shaykhmuhammad-baazmool/

Abu, A. (2014). "In Pursuit of Ikhlas". https://muslimmatters.org/2014/03/07/in-pursuit-ofikhlaas/

Ahmad, I. (2005). The Obligations Muslims owe to the Qur'an. Lahore: Markazi Anjuman Khuddam-ul-Qur'an Lahore.

Al-Bukhari, M. (1997). Sahih al-Bukhari. Riyadh: Darussalam publishers and distributors.

Al-Hajjaj, M. (n.d). Sahih Muslim. https://sunnah.com/muslim

Al-Nawawi, A. Z. (1999). The forty hadith of al-Imam an-Nawawi: Text with explanatory notes. Jeddah: Abul-Qasim publishing house.

Al-Qaradawi, Y. (1998). Islam: The Future Civilization. Cairo: El-Falah Foundation for Translation, Publishing \& Distribution.

Al-Zubaydi, A. (1971). Ithaf al-Sadat al-Muttaqin bi Sharhi Ihya' 'Ulum al-Din. Vol.1. Lebanon: Dar al-Kutub al-'Ilmiyyah.

Asad, M. (1980). The Message of The Qur'an: Translated and Explained. Gibraltar: Dar alAndalus.

Chittick, W. C. (1989). The Sufi Path of Knowledge: Ibn al-Arabi's Metaphysics of Imagination. Albany: State University of New York Press.

Ibn Anas, M. (1989). Al-Muwatta'. London" Routledge.

Ibn Hanbal, A. (1985 AD./1416 AH). Al-Musnad. Cairo: Dar al-Hadith.

Ibn Hibban, A. H. (2012). Sahih ibn Hibban. Beirut: Dar Ibn Hazm.

Ibn Rajab, A., \& Ajmai, M. (1995). Bayan Fadhl 'ilm al-Salaf 'ala 'ilm al-Khalaf. Bayrut: Dar alBasha'ir al-Islamiyyah.

'Iyadh, A. A. (1970). Al-Ilma' ila Ma'rifat Usul. Al-Qahirah: Dar al-Turath.

Khattab, M. (2016). The Clear Qur'an: A Thematic English Translation of the Message of the Final Revelation. Canada: Siraj Publications and Book of Signs Foundation.

Welter, B. W., \& Egmon, J. (2006). The Prepared Mind of a Leader: Eight Skills Leaders use to Innovate, Make Decisions, and Solve Problems. San Francisco: Jossey-Bass.

Moore, T. (1992). Care of the Soul: Guide for Cultivating Depth and Sacredness in Everyday Life. New York: HarperCollins Publishers, Inc.

Sivananda, S. (2011). How to Cultivate Virtues and Eradicate Vices. Uttarakhand: Himalayas, India.

Valliani, A. (2013). "Importance of Reading". https://www.newageislam.com/islamicsociety/amin-valliani/importance-of-reading/d/35114

Yohannan, K. P. (2008). Touching Godliness through Submission. Carrollton: GFA books. 